Spring 2007

\title{
On Empire's Shore: Free and Unfree Workers in Galveston, Texas, 1840-1860
}

Robert S. Shelton

Cleveland State University, r.s.shelton@csuohio.edu

Follow this and additional works at: https://engagedscholarship.csuohio.edu/clhist_facpub

How does access to this work benefit you? Let us know!

\section{Publisher's Statement}

Copyright 2007 Carnegie Mellon University Press. Available on publisher's site at

http://www.jstor.org/stable/4491945.

\section{Original Citation}

Robert S. Shelton, "On Empire's Shore: Free and Unfree Workers in Galveston, Texas, 1840-1860," Journal of Social History 40 no. 3 (2007): 717.

\section{Repository Citation}

Shelton, Robert S., "On Empire's Shore: Free and Unfree Workers in Galveston, Texas, 1840-1860" (2007). History Faculty Publications. 2.

https://engagedscholarship.csuohio.edu/clhist_facpub/2

This Article is brought to you for free and open access by the History Department at EngagedScholarship@CSU. It has been accepted for inclusion in History Faculty Publications by an authorized administrator of EngagedScholarship@CSU. For more information, please contact library.es@csuohio.edu. 


\title{
ON EMPIRE'S SHORE: FREE AND UNFREE WORKERS IN GALVESTON, TEXAS, $1840-1860$
}

\author{
By Robert S. Shelton
}

Cleveland State University

During the summer of 1854 the editor of a Texas newspaper wrote in anguish that dances attended by blacks and working-class whites were common in the state's larger cities and that anyone observing such an event "almost imagines himself in the land of amalgamation, abolition meetings, and women's rights conventions." The illegal but common practice of allowing slaves to hire out their own labor and find their own housing, the editor complained, had led them to "impudence" and the taking up of such alarming habits as smoking, gambling, drinking, and carousing with "low, unprincipled white men," who "because they are conscious that they do not deserve the respect of decent persons of their own color ... resort to Negrodom for society and sympathy." If such practices were left unchecked by proper authorities, the editor warned, "we will ere long have a Southampton insurrection, or a general Negro stampede for Mexico." The editor then urged the board of aldermen to enact stricter ordinances to control the behavior of slaves-and of "low, unprincipled" whites. ${ }^{1}$

As the editor's observations suggest, in antebellum southern cities such as Galveston-the small but thriving seaport that served as Texas's commercial emporium - poor whites and enslaved African-Americans at times interacted in ways uncommon in southern slave society and unsettling to the slaveholders whose economic, social, and political dominance required a unified white commitment to black inferiority. Social interaction among enslaved black and "common" white people, who shared few of the material advantages of white supremacy, represented a dangerous blurring of established racial lines and posed a potential threat to the social control of slaveholders and to the rigid hierarchy of southern slave society. Such relations did indeed develop, however, as African-American bondspeople and white casual laborers in Galveston spent much of their waking hours together working at the most menial and arduous tasks; living side-by-side in cheap houses, shacks, and shanties; and socializing in homes, liquor stores, brothels, saloons, and on beaches away from the immediate supervision of authorities. As in other antebellum port cities, the degree of interracial socialization in Galveston worried the slaveholding elite to such an extent that the city repeatedly passed laws carrying increasingly harsh penalties designed to draw more clearly the color line between black and white workers. ${ }^{2}$

Historians have long recognized that the urban landscape proved inhospitable to the kind of slavery found on the South's plantations. In southern cities, common practices such as allowing slaves to find their own jobs, earn their own wages, rent their own dwellings, and manage their own time bred an independence that eroded the discipline of slavery. Moreover, as scholars have abundantly documented, and slaveholders frequently lamented, free black city. $d$ wellers further undermined slavery by providing enslaved African-Americans information, sources and markets for illicitly traded goods, domestic partners, and temporary and permanent refuge. ${ }^{3}$ Perhaps what distinguished Galveston 
among southern urban areas, however, was the virtual absence of free persons of color —only two by 1860 owing to state and local laws that drove free blacks out of the state, into hiding, or back into slavery. Consequently, in Galveston slaves had far more contact with poor white casual laborers than with free black people. Yet even in areas of the South with large free black populations varying degrees of interaction between enslaved African-Americans and poor non-slaveholding white people have been discovered by scholars studying northern colonial cities and the antebellum southern countryside. ${ }^{4}$ Furthermore, scholarship of Atlantic seamen in the eighteenth and nineteenth centuries has revealed a rough equality, albeit frequently marked by racism and white supremacy, that existed in the maritime world on ship and shore. ${ }^{5}$ These findings modify the conclusions of historians who have argued that the legal segregation that emerged at the end of the nineteenth century originated during Reconstruction as an alternative, accepted by African-Americans, to the exclusion of black people from public accommodations and services that had prevailed during the period of slavery. ${ }^{6}$

Certainly, during the antebellum period tradition and habit, if not law, excluded free blacks and slaves, except as servants, from institutions used by the South's white elite and middle classes. In Galveston, for example, there were few municipal or state laws that specifically prohibited African-Americans from establishments frequented by white people, yet it is clear that black residents of the city did not attend balls thrown for the elite, eat in the restaurants frequented by middle and upper class diners, drink in gentlemen's clubs or taverns, or patronize most businesses. One of the few institutions that did allow black participation was the Methodist Church, which in the 1840s began providing separate services for African-American worshipers. ${ }^{7}$ Such racial exclusivity no doubt conditioned Euro-American workers to the practices of white supremacy. Despite the racism that pervaded all strata of southern cities such as Galveston, however, on the margins of society such exclusion, while perhaps traditional, was not habitual. This article furthers the excavation of a little-worked field of inquiry by focusing on the interactions between black slaves and the poorest of the South's urban whites-casual laborers who worked at whatever low-paying, low-skilled jobs they could find-and by suggesting why such benign interactions developed in a region where social relations based on domination, fear, and repression usually prevailed.

In 1846, after a decade of desultory independence, Texas joined the United States, expanding the South's cotton-slave frontier westward and promising to take its place as the most bountiful plantation region in the country. From 1850 to 1860 the state rose to become the fifth-leading cotton producer in the nation, and observers predicted even more spectacular growth as more slaves and better transportation opened up more of Texas's fertile lands to agriculture. Texas, as the editor of the Austin Texas State Gazette prophesied, was destined to become the "Empire State of the South." ${ }^{8}$ On the shores of this potential empire of cotton and slaves, Galveston also awaited the fulfillment of its promise. Located on a barrier island about 300 miles west of New Orleans, the city possessed one of the best natural harbors on the Gulf of Mexico, and its boosters crowed that if Texas became the South's Empire State, Galveston would be its New York City. Galveston, another editor predicted, "will undoubtedly, at no distant day, become the center of commerce rivaling in extent that of many of the first 
commercial cities of the world. The products of many millions of acres of the most fertile lands on the globe, and of many rich mines of gold, silver, and iron, will necessarily be wafted to this spot, rendering Galveston City the commercial emporium of Texas."

Although the city eventually lost its commercial pre-eminence to Houston, such predictions seemed justified in the antebellum era. The state's richest plantation districts lay in the counties surrounding Galveston, making the city a natural egress for slave-grown produce. By 1860 Galveston had become the state's second-largest city with more than 7,000 residents, its cultural center, and its leading commercial hub. ${ }^{10}$ Most of the state's cotton, sugar, and rice exports passed over the city's wharves, and ships from Europe, the Caribbean, and South America as well as New York, Boston, Baltimore, and New Orleans regularly called on the port. ${ }^{11}$ Galveston's leading businessmen-cotton commission agents and speculators, slave traders, and absentee plantation ownerswere among the wealthiest men in Texas, shaped the state's policies, and dominated the city politically, economically, and socially.

At the bottom of Galveston society, however, resided two groups of people who possessed little wealth, few prospects, and, for some, not even themselves. The first of these groups, white casual laborers, constituted perhaps one of every five residents who listed occupations in the 1850 and 1860 censuses. Casual laborers worked at low-paying jobs that could not be counted on as regular sources of income and were perceived as requiring little skill to perform. Such jobs included working as unskilled labor on construction sites, collecting and dispersing oyster shells for the city's streets, rolling cotton at the cotton presses, keeping the streets clear and in repair, hauling fill for low spots in the city, digging cisterns, cleaning privies, performing domestic labor, taking in washing and sewing, selling sexual services, hauling cargo to and from warehouses, working on Galveston's wharves loading and unloading the ships calling at the port, and carrying passengers through shallow water to and from ships anchored in the harbor awaiting their turn at the wharves. ${ }^{12}$ The other group, enslaved AfricanAmericans, constituted as much as 17 percent of the city's antebellum population. As in other southern cities, enslaved black people often found their own lodgings and employment, which provided them not only with greater freedom than plantation slaves but also brought them into daily, close contact with poor white workers. Although many bondsmen found work in various skilled tradesit was frequently reported by observers that skilled work in Galveston was performed by slaves and European immigrants-most worked at the variety of tasks performed by white casual laborers, often working at these tasks together.

In 1854 , for example, a visitor to the city noted that slaves joined white men lightering cargo from ships anchored outside the sandbar that prevented the deepest draught vessels from entering the harbor. One visitor to the city remarked that the slaves and casual laborers sang together as they loaded and unloaded vessels tied along the city's wharves. Enslaved black men also worked as cotton screwmen alongside white men. Working in gangs of four or five men, the screwmen, or cotton jammers, used large jackscrews to compact cotton bales into the holds of ships. The work was hard and dangerous and required coordination and cooperation among the gang members. Longshoring work for shipping companies and individual ships' captains employed men of both colors. When 
the schooner Nameaug arrived in Galveston in 1856, for example, white "steveders" helped the crew, which included black seamen, load cotton bales, molasses, sugar, and tanned hides for its return voyage to Boston, Massachusetts. ${ }^{13}$ Both cotton jamming and longshoring paid better than other forms of casual labor but were seasonal and thus perhaps more irregular in nature. Another dangerous task shared by enslaved and free workers involved salvage operations. The cargoes of ships grounded on Galveston Bay's numerous sandbars or sunk by storms were retrieved by African-Americans and poor whites hired by the ships' owners or the commission house responsible for the cargo. ${ }^{14}$ It could be dangerous work that not infrequently resulted in drowning. In 1856, for example, a white man identified as $\mathrm{F}$. Schoenenfield drowned in the harbor when he became trapped in a sunken vessel despite the efforts of several slaves and other white men also working the salvage to save him. ${ }^{15}$

Enslaved black people and free white people also found themselves working and sometimes living side by side as domestic servants. Slaves and white servants not only mingled while performing such tasks as shopping at the city's markets and groceries but also occasionally lived with one another in the same house and sometimes even the same rooms. The 1850 and 1860 census shows that approximately one-quarter of households had a young adult of a different name and often of different nationality living in them. Evidence suggests that at least some of them performed domestic duties in return for room and board. ${ }^{16}$

Slaves hiring their own time or hired out by their masters often worked with poor white men for the city. In 1851, for example, the city contracted with John S. Sydnor to fill low spots throughout Galveston. The city regularly contracted for this work in an effort to prevent the accumulation of standing water that they and other nineteenth-century Americans vaguely associated with deadly yellow fever outbreaks. Sydnor, who operated the largest slave auction in town and frequently rented out his inventory before their sale, billed the city $\$ 1.25$ per day for use of a slave and $\$ 1.50$ for a white man. In $1849 \mathrm{E}$. O. Lynch, one of the largest slaveholders in the state, billed the city for repairing streets and digging a cistern. His bill for the work showed that he had employed his own slaves and white men. At construction sites enslaved black men and poor whites also worked together as common laborers. ${ }^{17}$ In a lawsuit filed in 1848 Sydnor sought remuneration for the hire of a slave and white man for helping a white carpenter build shelving in a grocery store. Gilbert Winney, owner of a livery stable in 1850, owned a thirty-year-old male slave who worked with his two white livery keepers, French immigrant Lewis Boneall and a middle-age Pennsylvanian named John Magill. Court records from the 1840 s and 1850 s occasionally mention white and black people working together to perform such tasks as moving outbuildings, cutting firewood, pressing cotton, constructing buildings, filling land, digging ditches, and draying goods from warehouse to wharf. ${ }^{18}$ This is not to suggest that relations between black and white workers were free of animosity stemming from job competition or white racism. Although there is little documented evidence of conflicts between enslaved black people and casual white laborers during the antebellum period, no doubt insults flew, fights erupted, and racial antagonism festered at work and in social situations. During the Civil War, for example, Irish casual laborers from Galveston pledged support for the Confederacy and slavery and formed their own company that saw action in Louisiana. Furthermore, 
in the years following emancipation, longshoremen and cotton screwmen, who constituted a large segment of the casual labor force in antebellum Galveston, attempted to ban blacks from waterfront work, which was the most reliable and highest-paying labor in the port city. The dramatic changes wrought by emancipation, beyond the scope of the present study, increased economic and political competition between black and white workers and no doubt thereby increased incentives for Euro-Americans to embrace white supremacy. The ease at which they did so indicates that racism figured significantly in antebellum relations as well. It is worth noting, however, that it was not until late 1869 that white waterfront workers excluded black workers from their unions and attempted to do so from the docks, suggesting the new competitive environment and the possibility that racial exclusion was not an automatic, unconsidered reaction to emancipation. Furthermore, Galveston's antebellum white elite considered working-class saloons and brothels lawless and dangerous owing to the brawling that broke between patrons-certainly sometimes because of racial enmity.

Yet brothels, as historian Ira Berlin has noted, were perhaps among the most integrated places in the South. In Galveston, enslaved and free black women and white women lived and worked under the same roof in the city's houses of prostitution. On the city's east and west sides and in the alleys a few blocks off the waterfront stood several houses of prostitution such as Fanny Hill's "house of ill fame," whose "fancy girls" were enslaved black women and free white women. According to the Galveston Weekly News, the brothels catered to "the rougher element" of men of all colors, who could drink alcohol, gamble, and "carouse loudly throughout the night."19 Attempting to remove such establishments from commercial and residential areas, the city council in 1857 restricted the operation of houses of prostitution to the far western end of the city among the cotton presses and warehouses. White men or women operating a brothel anywhere else in the city faced a $\$ 100$ fine and fifteen days in jail; free women of color risked being hired out for six months to the highest bidder; free men of color, six months hard labor working under the direction of the city marshal. ${ }^{20}$

The city's response to the carousing at brothels demonstrates that Galveston's slaveholding elite intended to prevent interracial association outside the workplace-in brothels, saloons, pool halls, grog shops, alleys, and private homes. ${ }^{21}$ Yet legal and illegal associations between black slaves and white workers occurred frequently. In Galveston, biracial social interaction often occurred because slaves who lived apart from their owners often lived in the neighborhoods where most of the city's casual laborers dwelled. On the west side of the city these neighborhoods lay near the cotton presses and warehouses; on the east side, beyond one of the main markets. In the center of town, the extensive alleyways often became virtually impassable owing to the number of ramshackle homes erected in them. Together these neighborhoods enclosed the commercial center of town on the waterfront. The Galveston City Company, which had title to all the unsold land in the city, owned many small houses in these neighborhoods that were rented to laborers, to slaves or slaveholders, or to free persons of color. Boarding houses that in the late 1850s charged $\$ 2.50$ to $\$ 4$ per week for a room with multiple occupants could be found here. ${ }^{22}$ Some laborers owned small houses, most of which were valued at less than a quarter of even the least-valued homes in other portions of the city. One worker recorded 
that a house measuring sixteen by twenty-four feet and occupied by nine people sold along with its furnishings for $\$ 5,000$ - a figure far beyond the means of most unskilled workers who typically earned no more than $\$ 30$ per month. ${ }^{23}$ The slaves in these areas lived apart from their owners, who usually resided in the more upscale portions of town. In the 1840s and 1850s, local newspapers often complained about the "pest houses," inhabited by enslaved black people, that infested various parts of the city. In April 1854, the city council's report on city-owned property found that city property along Broadway had been "seized upon by three trespassers on the North side who have erected 'hovels' that are for rent." The other portion of the property "seems to be in the occupancy of a negress with an old hovel-like building." The city passed ordinances to clear the alleys of "hovels" and other structures that grew up to provide accommodations for poor whites and living-out black slaves. ${ }^{24}$

Most slaves, however, lived with their owners, or rather behind their owners, in slave houses that often lined the city's alleyways in the more prosperous Second Ward. Yet even slaves who lived on their masters' premises frequented the saloons and shops in the less reputable neighborhoods. As one observer noted, the slaves of Galveston could be seen in all parts of the city going on various errands for their masters or at their leisure. The city's newspapers repeatedly expressed dismay at the number of slaves and "poorer sorts" of whites who congregated around grog shops, groceries, gambling tents in the alleys, and pool halls. The city council, at the urging of Galveston slaveholders, repeatedly increased the severity of punishments for slaves buying liquor or whites selling liquor to slaves. "Let anyone travel through the suburbs of our city and note the number of our little whiskey shops (called groceries to give them more respectability) out and into which he may see negroes coming and going at night, and on Sundays, and he cannot fail to be satisfied that this negro traffic is carried on most systematically." 25 In 1857 the city raised the licensing fees for the operation of groceries, beer halls, grog shops, and saloons and increased the fines and jail time for anyone operating one without a permit. At the same time the city council increased the penalties for white people who allowed enslaved black people to drink or gamble in private homes, enacted harsher measures against slaves who hired their own time or found their own living arrangements, and raised the fines for slaveholders who permitted their slaves to do so and for anyone who rented or hired a slave without the permission of his or her owner. ${ }^{26}$

Dances also occurred fairly regularly and were of great concern to slaveholders. In 1852, for example, the slaves of Joseph Bates held a ball that was attended by "negros finely turned out" and a smattering of less well-appointed white people. ${ }^{27}$ Such balls prompted the city council in 1854 to require slaveholders to obtain permission from the city council before holding any sort of entertainment for groups of five or more slaves. The same ordinance increased the punishment from ten to thirty-nine lashes for slaves who congregated without their masters' permission and provided for jail time for whites who allowed slaves to congregate in their homes without the permission of the slaves' owners. ${ }^{28}$

The waterfront also provided slaves and laborers who worked along it opportunities for socializing. Visitors in the 1840 s and 1850 s noted that black and white people frolicked on the beach, "making the air sound with their songs and shouts of revelry." Other visitors noted that even on the wharves during the 
summer men of both colors could be seen swimming, diving, and horse-playing together in the harbor with what one observer called a "disgraceful lack of decorum and an obscene lack of dress." In 1857 the city passed several ordinances proscribing this activity, making it illegal for men or women to "divest themselves of their clothing for the purpose of, or under the pretense of, bathing" on the beaches of the bay or gulf or along the wharves. The wording-"under the pretense of bathing"- - suggests that perhaps more than skinny-dipping was occurring. Virtually no hard evidence exists that interracial sex occurred between casual workers and slaves, or between slaveowners and slaves, for that matter. The number of people census enumerators classified as "mulattoes" represented about 25 percent of the slave population in 1850 and 20 percent in 1860 . In 1850 , about 36 percent of "mulattoes" were young enough to have been born in the city; in 1860,64 percent. So assuming that census enumerators and slaveholders knew and accurately represented the racial background of slaves-a very large assumption-it seems clear that though the percentage of mixed-race individuals decreased during the decade the number born in the city may have increased substantially. Nevertheless, the lack of information about the provenance or parentage of the enslaved people in Galveston makes it all but impossible to reliably infer from demographic statistics the extent of interracial sex. Certainly, no evidence remains to suggest that interracial sexual relations occurred beyond the walls of brothels. ${ }^{29}$

By 1861 the city had enacted a rigorous slave code that prohibited slaves from hiring their own time, finding their own dwellings, buying or drinking liquor, gambling, congregating in groups of five or more without permission, holding dances without permission, and going about on their own after sunset without a pass from their owners. White people who inveigled slaves to break these laws faced fines and jail time. The city also enacted in the late 1850s a strict vagrancy law that made it a crime to be unemployed and not looking for work. Enslaved and free men and women found loitering on the sidewalks were to be arrested and put to work on the city's streets under the direction of the marshal. This law was so successful that the Galveston Daily News, the voice of conservatism in the city, recommended an amendment to it to relieve overcrowding in the city jail by inmates who "would work when work was at hand." The ordinance, however, remained in place until the end of the Civil War. ${ }^{30}$

Clearly, black and white Galvestonians formed associations at work that carried over to social interactions after the work day was done. Why did such interaction occur and why did it worry slaveholders in the city? The daily interaction between white workers and enslaved African-Americans noted above, the composition of the white casual workforce, and the circumstances of their lives must figure prominently in any explanation. Among white people, recent arrivals overwhelmingly performed casual labor in Galveston. During the $1840 \mathrm{~s}$ and 1850 s, a steady stream of immigrants from the United States and Europe flowed through the city. Although most of the newcomers stayed only a short time before striking out for the interior, where cheap and abundant land beckoned would-be farmers, many others remained for years or stayed permanently, boosting the city's population during the decade before the Civil War from 4,177 to 7,328. Native-born Americans dominated the skilled trades and white collar jobs in small business, medicine, the law, and government, and those that 
worked at casual labor did so only for a short time as a step up the economic ladder. "Many of our most prominent residents earned their first money by carrying passengers and freight to and from vessels on their strong shoulders," one nineteenth-century writer noted about a job commonly available before the construction of wharves from shore across the shallows to the harbor channel. ${ }^{31}$

Casual labor, on the other hand, rarely provided a basis for social mobility. Many casual laborers were immigrants-in 1860 nine out of ten of men listed as "laborers" were foreign-born-and frequently stayed only a short time in Galveston before moving on. "There are more men in this town who are dissatisfied and wish to get out of it than in any town I was ever in before," stated a working man from Minnesota who spent the winter of 1859 in Galveston. This transience, typical of the antebellum American urban poor, makes it difficult to determine from the federal censuses the persistence of casual labor. Of the more than 1,000 Galvestonians with occupations enumerated in the 1850 federal census, for example, only two-hundred also appeared in the 1860 census. Of these, fewer than ten had been listed as "laborers" in 1850; all were engaged in casual labor in 1860 as well. Some who remained casual laborers, however, prospered. For example, Antone Herman, an immigrant from Prussia who arrived in Galveston in 1848, listed his occupation in 1850 as "hunter"-probably stalking the wild game of Galveston Island and Southeast Texas for sale in the city market. By 1860 , he was listed in the census as a laborer, but probably continued to supplement the family income through hunting since in 1870 he again claimed hunting as his main occupation. By that time, however, he was also a member of the Screwmen's Benevolent Association, an organization of longshoremen whose specialization in packing cotton into the holds of ships made them among the highest-paid unskilled workers in the last decades of the nineteenth century. Herman by 1870 had also managed to purchase a home and several other houses in Galveston and amassed personal property valued at $\$ 4,000$. Other laborers did not fare so well. Frederick Brandies, for example, remained a laborer during the decade of the 1850 s and though he managed to acquire a house, its value of $\$ 500$ represented one of the poorest such properties in the city. For casual laborers-frequently immigrants who had not been brought up to the social etiquette of slavery-the material benefits of white supremacy were not apparent. ${ }^{32}$

Their poverty and lack of a political voice in local affairs no doubt also made it clear to poor white Galvestonians that their material condition lay closer to that of the slaves than to the middle and upper classes in the city. In 1850, for example, 45 percent of the city's families possessed no real property, and another 25 percent owned less than $\$ 1,000$ worth of property. Thus more than three out of four working families in Galveston owned nothing or only small homes. On the other hand, 5 percent of heads of families possessed more than $\$ 10,000$ worth of real estate, and the wealthiest 4 percent of heads of households-those with more than $\$ 10,000$ in real estate holdings-owned 59 percent of all real estate in the town. Slaveholders, though representing only 4 percent of the total white population in 1850 and only 3.9 percent in 1860 , owned 51 percent of all real property in 1850 and 64 percent in 1860 . Slaveholders' share of personal property, which included slaves, was even greater-77 percent in 1860.33 Such disparity of wealth was clearly apparent. The fine houses of the elite and the 
modest but relatively spacious homes of the emerging middle class lay toward the gulf side of city, away from the noise and smells of the port. Most of the poor white and living-out enslaved black people, on the other hand, lived in oneor two-room houses, shanties, or shacks along the streets and alleys surrounding the port. Visitors noted that the wealthy not only dressed in the finest clothing themselves but strove on special occasions to outdo one another in dressing their bondspeople in the most extravagant clothing. ${ }^{34}$

Municipal politics, another avenue of opportunity that had opened for working men during the Jacksonian period, was not available in Galveston. ${ }^{35} \mathrm{Few}$ if any working-class men ever held state or federal office in Texas during the antebellum period and even at the local level, officeholding was dominated by slaveholders and their wealthy allies. During the antebellum period, for example, 62 percent of elective and appointive municipal offices were held by slaveholders. In 1860,96 percent of office holders owned slaves even though only 17 percent of all families held bondsmen. Frequently a single slaveholder held numerous municipal offices over the years. Lent Hitchcock, for example, served as alderman, harbormaster, and treasurer from 1839 through 1852 and was succeeded as treasurer by his son, Frank Hitchcock. Frank Hitchcock served as treasurer or port warden, an office with responsibility for examining ships for signs of disease, free black sailors, and runaway slaves, for almost a decade during the antebellum period. ${ }^{36}$

From Galveston's founding slaveholders took for granted their domination of the city politically. The town's first charter, approved by the Republic of Texas Congress on 28 January 1839, provided for a city council of eight aldermen, a mayor, and a recorder and required all officeholders to possess at least $\$ 500$ worth of real estate within the corporate limits. ${ }^{37}$ In consequence of the property requirements, only about thirty-five of Galveston's 3,000 residents possessed sufficient property to qualify for office. A charter revision in 1840 required voters to own at least $\$ 500$ worth of real estate. ${ }^{38}$ In February 1844 yet another new charter eliminated the property qualifications for voting, but instituted a $\$ 1,000$ property requirement for aldermen..$^{39}$ In 1856 the charter was amended again. The number of wards was increased to four and the number of aldermen was increased to twelve. Responding to agitation by white artisans, the city now allowed white males twenty-one and older who had rented at least twelve months previous to the day of the election and paid all poll taxes to vote. Property requirements for office holding, however, remained at $\$ 1,000$ for mayor and aldermen. ${ }^{40}$ As a result of the property requirements, in 1850 , only 20 percent of the white males twenty-one years or older qualified for officeholding. In 1860, the percent of white adult males eligible for office had increased to 36 percent of all white males older than twenty-one. Coincidentally, approximately 36 percent of Galveston's eligible residents actually voted in Texas's 1861 secession referendum, which passed in Galveston County 765 to 33, perhaps indicating a citizenry habituated to avoiding political affairs. ${ }^{41}$

Mired in poverty with few opportunities to improve their economic condition, so unmoored from the community that they eagerly sought their fortunes elsewhere, and virtually barred from political participation because they owned no property, Euro-American casual laborers clearly had little stake in the democracy of whiteness that racially cemented the white South together. Casual labor- 
ers, furthermore, worked with enslaved African-Americans at arduous, dangerous, and poorly paid jobs for hours and days at a time and often continued their associations beyond the workplace, giving rise to a benign association, if not an affinity, with the enslaved people with whom they worked, lived, and caroused. Consequently, Galveston's casual laborers did not seize upon a "white identity" that, scholars of "whiteness" assert, shaped the attitudes of free workers in the antebellum North. ${ }^{42}$ While Galveston's white workers no doubt knew that slavery legally placed black bondspeople below them in the South's social hierarchy, the common experiences they shared with enslaved African-American suggests that at times, at least, they recognized their common humanity. The enslaved people, practiced at maintaining wary relations with white folk, nevertheless psychologically benefited from the acceptance implicit in their interactions with white workers and recognized that such relationships could prove materially beneficial in their struggle with slavery. Despite the dearth of evidence of the attitudes of white and black laborers toward each other, and despite the certainty that animosity and suspicion characterized some or even most of the relationships between them, a rough equality not uncommon among denizens of Atlantic port cities existed at times that undermined the rigid white supremacy expected by slaveholders and others who supported the southern slave regime. It is clear from the repeated efforts of the city's slaveholding elite to curb biracial interaction and forestall relationships from developing that they recognized the threat such relations posed to slavery and the social system based upon it. Slaveholders never questioned the "whiteness" of casual laborers, but rather regarded them with contempt for occupying a low social strata that brought them into daily interaction with slaves and that thereby led them to forsake the principles and moral duties of white supremacy. Such racial apostasy, slaveholders believed, upset the social order by encouraging otherwise docile black people to strain against the bonds of slavery. "It is no easy matter," wrote one slaveholder, "to estimate the influence a few vulgar, unprincipled white men can, in a short time, exert over a large community of ignorant negros, who, if not tampered with, would remain quiet, inoffensive and dutiful." ${ }^{43}$

Department of History

2121 Euclid Avenue, RT 1915

Cleveland, $\mathrm{OH} 44115-2214$

\section{ENDNOTES}

Research for this article was made possible in part through the support of the Paul Cuffe Memorial Fellowship for the Study of Minorities in American Maritime History from the Munson Institute of Maritime Studies at the Mystic Seaport Museum.

1. Austin State Gazette, 22 July 1854.

2. Ira Berlin and Herbert Gutman, "Natives and Immigrants, Free Men and Slaves: Urban Workingmen in the Antebellum South," American Historical Review 99 (December 1983), 1177. See also Timothy Lockley, Lines in the Sand: Race and Class in Low Country Georgia, 1750-1860 (Athens, GA, 2001): Chapter 3; Michele Gillespie, Free Labor in an Unfree World: White Artisans in Slaveholding Georgia, 1789-1860 (Athens, GA, 2000): 
131-134; John Gjerde, "Here in America there is neither King nor Tyrant:" European Encounters with Race, "Freedom" and their European Pasts, Journal of the Early Republic, 19 (1999), 673-690; John Bezis-Selfa, "A Tale of Two Ironworks: Slavery, Free Labor, and Resistance in the Early Republic," William and Mary Quarterly 56 (1999): 677-700; Free Labor in an Unfree World; Randall M. Miller, 'The Enemy Within: Some Effects of Foreign Immigrants on Antebellum Southern Cities', Southern Stuides, XXIV, (1985).

3. John Hope Franklin and Loren Schweninger, Runaway Slaves: Rebels on the Plantation (New York, 1999), 69-71, 109-111, 130, 28-279. Three of the most important studies that document the corrosive effects of city life on slavery are: Ira Berlin, Slaves without Masters: The Free Negro in the Antebellum South (New York, 1974); Richard C. Wade, Slavery in the Cities: The South, 1820-1860 (New York, 1964), 250-252; Barbara Jeanne Fields, Slavery and Freedom on the Middle Ground: Maryland during the Nineteenth Century (New Haven, 1985), 3-4, 28-38.

4. David T. Gleeson, The Irish in the South, 1815-1877 (Chapel Hill, 2001), 124129; see also, Fred Siegel, "Artisans and Immigrants in the Politics of Late Antebellum Georgia," Civil War History 27 (September 1981): 21-30. Jeff Forret, "Slaves, Poor Whites, and the Underground Economy of the Rural Carolinas," Journal of Southern History LXX (November 2004): 783-824. Several excellent studies of African-Americans in the antebellum South discuss the relations among waterfront workers in port cities, which shared with northern ports an open, cosmopolitan character that militated against strict racial hierarchy. For southern ports, see David S. Cecelski, The Waterman's Song: Slavery and Freedom in Maritime North Carolina (Chapel Hill, 2001), 37-39; Christopher Phillips, Freedom's Port: The African American Community of Baltimore, 1790-1860 (Urbana, 1997), 30-113; Fields, Slavery and Freedom on the Middle Ground, 40-62; Bernard E. Powers Jr., "Black Charleston: A Social History, 1822-1885" (Ph.D. diss., Northwestern University, 1985), 20-22; Whittington Bernard Johnson, Black Savannah, 1788-1864 (Fayetteville, AR, 1996), 85-132; Betty Wood, Women's Works, Men's Work: The Informal Slave Economies of Lowcountry Georgia (Athens, GA, 1995), 81-121; Graham Russell Hodges, Slavery, Freedom and Culture among Early American Workers (Armonk, N.Y., 1998), 127-144. For northern port cities, see for example, Paul A. Gilje, Liberty on the Waterfront: American Maritime Culture in the Age of Revolution (Philadelphia, 2004), 2527,63 .

Other historians have argued that for political, social, economic, and psychological reasons, European-American workers in the antebellum North embraced a "white identity" that precluded the development of cordial relations with African-Americans and bolstered white supremacy. See David R. Roediger, The Wages of Whiteness: Race in the Making of the American Working Class (New York, 1991); Matthew Frye Jacobson, Whiteness of a Different Color: European Immigrants and the Alchemy of Race (Cambridge, MA, 1998); Noel Ignatiev, How the Irish Became White (New York, 1995). For cogent criticism of "whiteness" studies as an interpretive framework, see Arnesen, "Whiteness and the Historians' Imagination," International Labor and Working Class History 60 (Fall 2001): 3-32; and Peter Kolchin, "Whiteness Studies: The New History of Race in America" Joumal of American History 89 (June 2002): 154-173.

5. Marcus Rediker, Between the Devil and the Deep Blue Sea: Merchant Seamen, Pirates and the Anglo-American Maritime World, 1700-1750 (New York, 1987) argued that seamen in the eighteenth century represented a maritime proletariat whose cosmopolitan perspective, shared experiences, respect for nautical skills, and common exploitation, created a rough equality at sea and on shore, 29, 62-63, 68; W. Jeffrey Bolster, on the other hand, argued that racism and white supremacy pervaded this maritime world. Yet 
Bolster noted that at sea, respect for nautical skill often muted racism and that AfricanAmerican seaman often identified themselves and were identified according to circumstances by race, class, or skill, Bolster, Black Jacks: African American Seamen in the Age of Sail (Cambridge, MA, 1997), 35.

6. Howard N. Rabinowitz, Race Relations in the Urban South, 1865-1890, (Athens, GA, 1996), 97-98, 128. Rabinowitz, however, does admit that enslaved and free black people found opportunities in southern cities, 62-63; Howard N. Rabinowitz, "From Exclusion to Segregation: Southern Race Relations, 1865-1890," Joumal of American History 63 (1976): 325-350.

7. W. A. Droddy Diary, transcript, Center for American History, University of Texas at Austin, 7 June 1846; there was also an "African church" in Galveston in the mid-1840s, Fanny O. Trueheart (Galveston) to Kitty T. Minor (Thompson's Cross Roads, Virginia), 21 August 1846, Trueheart Family Papers, 1822-1904, Rosenberg Library, Galveston, Texas.

8. Earl Fornell, The Galveston Era: The Texas Crescent on the Eve of Secession (Austin, 1961), viii, 23; Randolph B. Campbell, An Empire for Slavery: The Peculiar Institution in Texas, 1821-1865 (Baton Rouge, 1989), 4.

9. Houston Telegraph, 19 August 1837.

10. Kenneth W. Wheeler, To Wear a City's Crown: The Beginnings of Urban Growth in Texas (Cambridge, MA, 1968), 120.

11. Fornell, 24; Charles W. Hayes, Galveston: History of the Island and the City from Discovery of the Island in 1526, from the Founding of the City in 1837, down to the Year 1879 (Cincinnati, 1879; reprint Austin, 1974), 1: 322-323; Richard G. Lowe and Randolph B. Campbell, Planters $\mathcal{E}$ Plain Folk: Agriculture in Antebellum Texas (Dallas, 1987), 18.

12. Antebellum census enumerators listed the occupation of workers so employed as "laborers," though other job descriptions such as draymen, cotton press operators, boatmen, also fall into the category of casual labor.

13. Hayes, Galveston, 1:322-323; Log 284, Manuscripts Collection, G.W. Blunt White Library, Mystic Seaport Museum, Inc. Also see Galveston Weekly News, 21 December 1858.

14. Fornell, 115-125; Paul D. Lack, "Urban Slavery in the Southwest," Ph.D. diss., Texas Tech University, Lubbock, Texas, 1973, 42-45; Mrs. Frederick M. Burton, History of Galveston, Texas (typescript, Southwest Collection, Texas Tech University), Letter \#16, p. 5; Galveston Weekly News, 21 December 1858; Wheeler, To Wear a City's Crown, 120.

\section{Galveston Weekly News, 25 September 1853.}

16. Manuscript returns of the Seventh Census and Eighth Census of the United States, Galveston County, Schedule 1, Free Inhabitants, Schedule II, Slave Inhabitants, 1850 and 1860 (microfilm, Fondren Library, Rice University, Houston, Texas); henceforth cited as Seventh Census or Eighth Census with appropriate schedule. 
17. Proceedings of the Mayor and Board of Aldermen for the City of Galveston, 18491855, City Secretary's Office, City Hall, Galveston, Texas, 30 August 1850, 30 September 1851, 3 February 1849.

18. Seventh Census, Population, Slave Inhabitants, John Sydnor v. C.C. Moore, et al., 1849; also see Thomas J. Lewis v. Joseph Bates, 1849, Thomas Lewis v. Elanor Spann, 1853, Charles Schaeffer v. Elisha O. Lynch, 1852, Records of the County Court, Galveston County Courthouse, Galveston, Texas.

19. Galveston Civilian and Gazette, 20 October 1857; Galveston Weekly News, 18 April 1855; Charter and Revised Code of Ordinances of the City of Galveston, 1856-1857, Rosenburg Library, 83.

20. Berlin, Slaves without Masters, 265. Charter and Revised Codes, 81,

21. For elsewhere on the south, see Timothy J. Lockley, "Crossing the Race Divide: Interracial Sex in Antebellum Savannah," Slavery \&ु Abolition 18 (1997): 159-173; Timothy J. Lockley, "Trading Encounters Between Non-Elite Whites and African Americans in Savannah, 1790-1860," Journal of Southern History 66 (2000): 25-48; also see Michele K. Gillespie, "Artisan Accommodation to the Slave South: the Case of William Talmage, A Blacksmith, 1834-1847," Georgia Historical Quarterly 81 (1997): 265-286; Michele K. Gillespie, "Planters in the Making: Artisanal Opportunity in Georgia, 1790-1830," in Howard B. Rock, Paul A. Gilje, and Robert Asher, eds., American Artisans: Crafting Social Identity, 1750-1850 (Baltimore, 1995): 33-47.

22. Eugene Marshall Papers, Diary, Special Collections, Duke University, Durham, North Carolina, 4: 4, 8, 90.

23. Reports of the Comptroller of Public Accounts, Ad Valorem Tax Division, Galve. ston County Real and Personal Property Tax Rolls, 1837-1888, Texas Room, Houston Public Library, Houston, Texas, 1855-60; henceforth referred to as Tax Rolls with appropriate year; Marshall Diary, 4:90.

24. Civilian and Galveston Gazette, 2 November 1844; Galveston Weekly News, 20 September 1853; Minutes of the City of Galveston, 1849-1955, Galveston City Clerk's Office, 1 April, 14 July, 20 July 1854.

25. Galveston Weekly News, 10 June 1856, 2 October 1856; 6 March 1860.

26. For editorials against the selling of liquor to slaves, see Galveston Civilian, 9 April 1856; Galveston Daily News, 21 March 1857; 7 November 1859; Revised Ordinances, 23.

27. Galveston Civilian, 7 May 1849 and 12 November 1852.

28. Galveston Civilian and Gazette, 22 July 1851; Revised Ordinances, 26, 57, 83.

29. Emmanuel Henri Diedonne Domeich, Missionary Adventures in Texas and Mexico: A Personal Narrative of Six Years' Sojourn in Those Regions. (London, 1859), 223; Hayes, Galveston, 1: 335, 347; Revised Ordinances, 83.

30. Revised Ordinances, 79-85; 45; Galveston Daily News, 12 July 1859.

31. Hayes, Galveston, 1:322. 
32. $1850,1860,1870$ Federal Censuses; Galveston County Tax Rolls. Marshall Diary, 4: 30. For the transience of Americans and the working class in particular during the nineteenth century, see Stephen Thernstrom, Poverty and Progress: Social Mobility in a Nineteenth Century City (Cambridge, MA, 1964); Michael B. Katz, Michael J. Doucet, and Mark Stern, The Social Organization of Early Industrial Capitalism (Cambridge, MA, 1982); Clyde Griffen and Sally Griffen, Natives and Newcomers: The Ordering of Opportunity in Mid-Nineteenth-Century Poughkeepsie (Cambridge, MA,1978).

33. Wealthholding figures for Galveston derive from Campbell and Lowe and from samples from the 1850 and 1860 federal population census. Seventh Census, Slave Inhabitants; Eighth Census, Slave Inhabitants.

34. Seventh Census, Slave Inhabitants; Eighth Census, Slave Inhabitants; Fornell, 116117.

35. For more on antebellum Texas politics see Walter L. Buenger, Secession and the Union in Texas (Austin, 1984); Robert Kingsley Peters, "Texas: Annexation to Secession" (Ph.D. diss., University of Texas ar Austin, 1977); Ernest Wallace, Texas in Turmoil: The Saga of Texas, 1849-1875 (Austin, 1965); for Jacksonian democracy, see Arthur M. Schlesinger, Jr., The Age of Jackson (Boston, 1945); Marvin Myers, The Jacksonian Persuasion: Politics and Belief (Stanford, 1957); William J. Cooper, Liberty and Slavery: Southern Politics to 1860 (New York, 1983).

36. Richardson and Richardson, Galveston Directory for 1859-1860, 33-35; Seventh Census, Slave; Eighth Census, Slave Inhabitants.

37. H.P.N. Gammel, comp., Laws of the Republic of Texas, 1839, (Houston, 1839), 4:9499.

38. Tax Rolls, 1840; Gammel, Laws of the Republic of Texas, 1840, (Houston, 1840), $266-273$.

39. Ibid.

40. H.P.N. Gammel, comp., Special Laws of the State of Texas, 10 vols., (Austin, 1898), $4: 154$.

41. Tax Rolls, 1840; Seventh Census, Free Inhabitants; Eighth Census, Free Inhabitants; Earnest William Winkler, ed., Joumal of the Secession Convention of Texas (Austin, 1912).

42. For criticisms of the concept of "whiteness" and identity as a category of historical analysis see Arnesen, "Whiteness and the Historians' Imagination," and Barbara J. Fields, "Whiteness, Racism, and Identity," International Labor and Working Class History 60 (Fall 2001): 48-56.

43. Austin State Gazette, 22 July 1854. 